\title{
Economic Diversification in GCC Economies: A Heaven for Investors
}

\author{
Humoud Almutairi ${ }^{1}$ \\ ${ }^{1}$ College of Life Since, Kuwait University, Kuwait \\ Correspondence: Humoud Almutairi, College of Life Since, Kuwait University, Kuwait. E-mail: \\ dr.humoud@gmail.com
}

Received: January 15, 2016

Accepted: March 9, 2016

Online Published: March 25, 2016

doi:10.5539/ijef.v8n4p84

URL: http://dx.doi.org/10.5539/ijef.v8n4p84

\begin{abstract}
Investors all over the world strive to a heaven for their investments. Strong economies tend to be the most desirable place for investments of all types. As one indicator of stable economies is the economic diversification, this study analyses and highlights improvements in economies of GCC as they strive to move beyond oil and petroleum sectors; grabbing attention of acute investors and global businesses and almost being in noticeable par with the seven largest emerging economies (the E7) that has monopolized the limelight.
\end{abstract}

Economic diversification of GCC Economies is analyzed by indirect approaches of measuring dependence of economic activity, budget and external accounts of productions and revenues generated by hydrocarbon sector and non-hydrocarbon sectors.

Non-Oil growth in GCC is expected to be around 8\% in the next 10 years (PwC Middle East Projections, 2013). A number of additional factors like politic stability, macro-economic reform and modernization, enhancement of private sector competitiveness that enhances growth have been noticeable in the GCC. For eg; UAE, Saudi Arabia and Qatar have the least demanding tax framework globally retaining top three positions in overall tax ranking (World Bank and PwC, 2014). In addition to the mentioned, building up of skills in the region by expats and nationals alike creates a huge opportunity, almost at par with the E7 marketing economies.

The author has cross checked observations based on Figures, tables and analysis with all publically available resources. Authorities like the IMF, the IIF, Central Bank reports and BNP Paribhas findings have been used for conclusions and generation of findings.

The inference is that GCC Economies have started to diversify from Hydro Carbon sectors at a slow, but steady pace due to depleting resources in various GCC states and Competition from various other countries in eth same field; creating an economic environment for investors and a huge pool of Job Opportunities in the future.

All data and Figures are taken with reference to publications from IMF, IIF, Central Banks and BNP Parabhas.

Keywords: GCC economies, Non-Oil sectors, growing economies

\section{Introduction}

\subsection{GCC Economies and Emerging Economic Trends}

The past decade has been a major economic transformation period for the members of the Gulf Cooperation Council. Diversifying economies away from oil sector was one major goal of economic policies. Non renewable nature of oil resource is a major factor that needs attention and is the prime reason of discussions for diversification of economies. This volatility of oil resources coupled with a rising pattern in demographic growth has instilled the importance of this topic amongst economic policies in the recent years.

GDP growth in the GCC is expected to outpace other growth markets, to the fact that the GCC authorities has massive investments in physical infrastructure like transport and power as well as programs that have been designed to improve employment opportunities, housing, health care and education across the GCC. 


\subsection{Growing Economies of the Gulf}

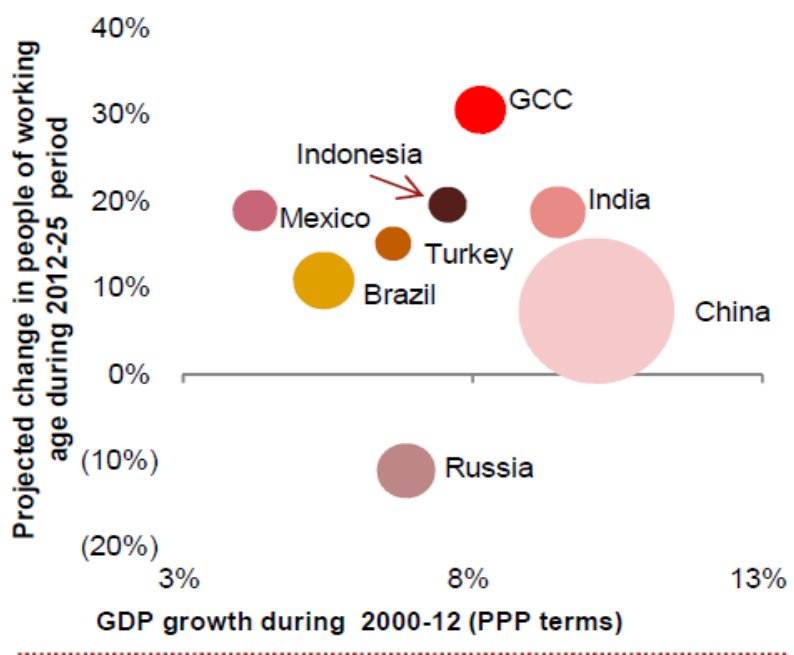

Size of the bubble indicates the size of the economy and is calculated using GDP at current market exchange rates. Source: IMF, PwC analysis

Figure 1. GCC and E7 market economies

According to Figure 1; in 2012, the GCC economies taken together were the third largest high growth market economy in the world. The size of GCC economies was equivalent to the size of Indian market economy. This has been calculated based on GDP at current market exchange rates). Over the period of 2000-2012; growth rate of GCC economies has been at $8.1 \%$ per annum compared to Russia which is $6.9 \%$ per annum.(PwC, 2013) This means that GCC economies have been faster than most emerging economies including Russia and Brazil.

\subsection{Factors Affecting GCC Economies}

Various factors have been instrumental in building up gulf economies. GCC economies have maintained a more pro business environment than other E7 economies (PwC, 2013). This is evident from Figure 2, which shows that all but one of the GCC economies ranks higher in the World bank's latest ease of doing Business Index than E7 economies. Among other GCC states, Saudi Arabia was ranked 22 ${ }^{\text {nd }}$, followed by the UAE (26), Qatar (40), Bahrain (42), Oman (47) and Kuwait (82) (Gupta, 2013).

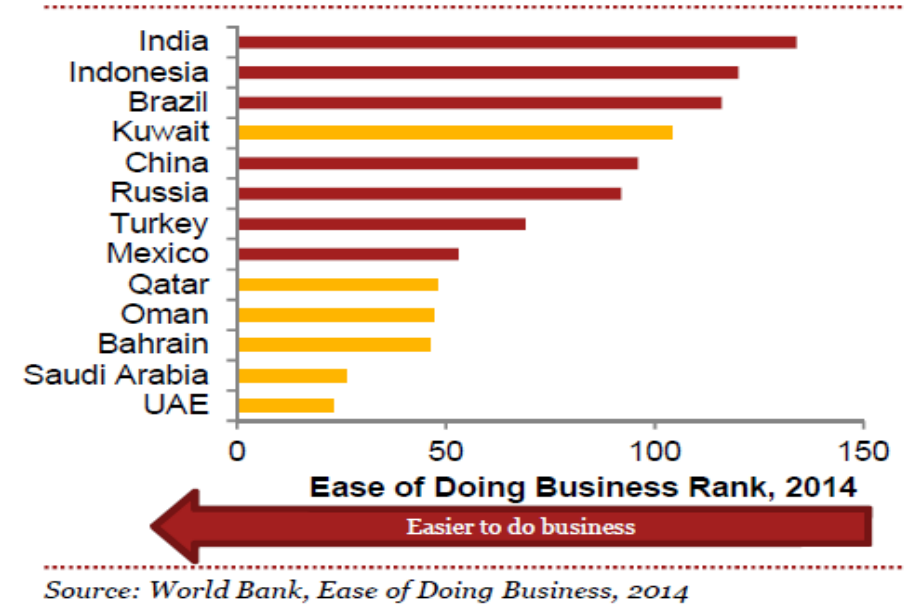

Figure 2. Ease of doing business rank, 2014

This has allowed and encouraged non oil related activity to flourish. (Zughaibi \& Kabbani General Partnership, 
2014). Figure 3 demonstrates that non oil and gas sectors account for a significant proportion of the GDP for some gulf countries along with hydrocarbons that account for the majority proportion. (Booz and Company, 2012) Bulk of non hydrocarbon growth has been in the services sector, partly reflecting grater spending on non-tradable by higher oil revenue. Majority of tradable are imported. Services have contributed to half of GDP growth and two thirds of non hydrocarbon growth. The period from 2000 onwards saw a considerable increase in the service sectors. Financial services grew rapidly in Bahrain, Kuwait, Qatar and the United Arab Emirates.

Government service grew remarkably in the region (Department of Foreign Affairs and Trade, Austrlian Government, 2005). Construction boom was pronounced in the UAE with Qatar and Oman in line. (Arcadis, 2013) Tourism grew rapidly in Saudi Arabia, with it being pronounced as the one amongst the top 20 destinations in the world for religious tourism(World Travel \& Tourism Council, 2014). Export based manufacturing industries grew in UAE and Bahrain.(Luciani, 2012) Sound economic systems in the GCC help them to weather financial crisis well. For example, the International Monetary Fund (IMF) recently stated that the Saudi Arabian "banking system remains well-capitalised, profitable and highly liquid"(IMF, 2013).

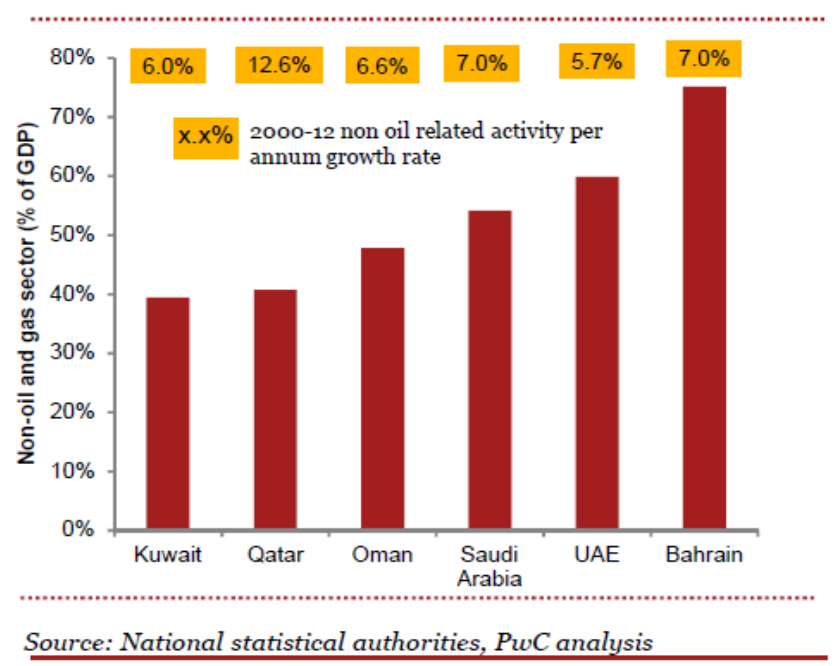

Figure 3. GDP from non oil and gas sectors in GCC

United Nations estimates that the potential workforce in the world will increase around a third by 2025 . This provides GCC with ample opportunities to diversify into the non oil and gas sectors, thereby creating jobs of the future it needs. Economic growth in the GCC has been labour intensive and associated with a large inflow of foreign labour. A large rise in private sector expatriate labour has been detected along with a considerable rise in public sectors of Kuwait and Qatar. (Samya, 2011).

As shown in Table below, between 2000 and 2010 approximately 7 million new jobs were created in the GCC, of which fewer than 2 million went to nationals. Many of the positions filled by expatriates were low-skill and low-paying construction jobs, but a large part also went to highly educated professionals for jobs where there was a shortage of nationals with the requisite skills.

Business Environment, Education and health portray a mixed picture in the business environment at international indicators. It hints that developments plans in the region would need to strengthen business environment further to support growth. While Saudi Arabia ranks high in the "Doing Business Indicator", other countries are ranked below the advanced country average (World Bank, 2013). Various reasons contribute to this. Enforcing contracts in GCC countries is a major problem. Oman and Qatar faces difficulties in obtaining credit for business while Kuwait and Qatar faces challenges in starting a business. Protecting investors and closing business in UAE and trading across borders in Kuwait poses to be setbacks in Business Environment. While Qatar and Saudi Arabia rank higher than the advanced country average, this poses a mixed range of weaknesses including health and education (in Kuwait, Oman and Saudi Arabia) and labour market efficiency in Kuwait and Saudi Arabia (Samya, 2011). 


\begin{tabular}{|c|c|c|c|c|c|c|c|}
\hline & & \multicolumn{4}{|c|}{2000 - 10 Estimate } & \multicolumn{2}{|c|}{2010 - 15 Forecast } \\
\hline & & $\begin{array}{l}\text { Total job } \\
\text { Creation }\end{array}$ & $\begin{array}{l}\text { Private Sector } \\
\text { job Creation } \\
\text { ( Thousands ) }\end{array}$ & $\begin{array}{l}\text { Public Sector } \\
\text { job Creation }\end{array}$ & $\begin{array}{l}\text { Total job } \\
\text { Creation }\end{array}$ & $\begin{array}{l}\text { Private Sector } \\
\text { job Creation } \\
\text { ( Thousands ) }\end{array}$ & $\begin{array}{l}\text { Public Sector } \\
\text { job Creation }\end{array}$ \\
\hline \multirow[t]{2}{*}{ Bahrain } & & 297 & 284 & 14 & 167 & 155 & 12 \\
\hline & Bahrain & 55 & 42 & 13 & 43 & 32 & 11 \\
\hline \multirow[t]{2}{*}{ Kuwait } & & 986 & 680 & 306 & 636 & 365 & 271 \\
\hline & Kuwait & 135 & 65 & 69 & 106 & 32 & 75 \\
\hline \multirow[t]{2}{*}{ Oman } & & 527 & 481 & 46 & 466 & 414 & 53 \\
\hline & Oman & 157 & 105 & 52 & 118 & 73 & 45 \\
\hline \multirow[t]{2}{*}{ Qatar } & & 1,118 & 1,078 & 40 & 865 & 827 & 39 \\
\hline & Qatar & 40 & 21 & 19 & 43 & 22 & 22 \\
\hline \multirow[t]{2}{*}{ U.A.E } & & 1,546 & 1,391 & 155 & 1,060 & 954 & 106 \\
\hline & Emirati & 110 & 99 & 11 & 84 & 75 & 8 \\
\hline \multirow[t]{2}{*}{ Saudi Arabia } & & 2,598 & 2,344 & 254 & 2,502 & 2,153 & 349 \\
\hline & Saudi Arabia & 1,302 & 1,068 & 234 & 1,172 & 865 & 307 \\
\hline Total & & 7,072 & 6,258 & 814 & 5,696 & 4,867 & 829 \\
\hline $\mathrm{o} / \mathrm{w}$ nationals & & 1,799 & 1,401 & 398 & 1,567 & 1,100 & 467 \\
\hline
\end{tabular}

Sources: Country authorities; and IMF staff estimates and forecasts.

Education and Health of the work force points to long term growth potential of an economy. According to the World Bank study of education in the Middle East and North Africa, once basic educational needs are met, effective participation in secondary and tertiary education requires more than just higher spending. (Human Development Network, 1998) (The World Bank, 2008).

\section{Methodology}

\subsection{Data}

GDP Data released from Eurozone was analyzed along with the PwC Global consumer Index. Also GDP data for GCC countries was analyzed from 2000 onwards, which projected to grow one third by 2025. IMF's release on "GCCC's enhancing economic outcomes in an uncertain way" laid figures and tables of data since 1990 on GDP dependency on hydrocarbons which were further analysed to strengthen the analysis.

\subsection{Measurement of Diversification}

Having to rely on breakdown of value added per sector makes it difficult for direct measurement of diversification. Therefore, indirect approaches of measuring dependence of economic activity, budget and external accounts of productions and revenues generated by hydrocarbon sector is the only possible way to measure the same.

Arab nation's tax revenues are small compared to the governmental income as corporate and household tax remain low. Hydro carbon revenues have been the most preferred source in Arab nations. Figure 4 depicts the slow change for the GCC Nationalities since 1990.

Shares of oil revenues when compared to total budget revenues are higher than $80 \%$ for all GCC countries. The last 20 years have shown a tremendous link to oil income with very minute changes in Bahrain, Saudi Arabia, Qatar and Kuwait.

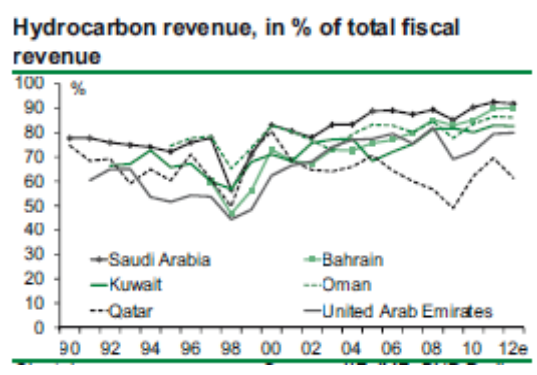

Figure $4 . \%$ of hydrocarbon and total fiscal revenue 


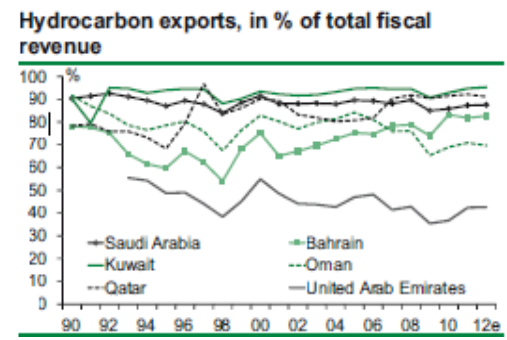

Figure 5. \% of hydrocarbon and fiscal revenue in Oman and UAE

In Figure 5; Oman, however shows a change in hydrocarbon exports to total exports from $90 \%$ to $65 \%$. Equally noticeable is merchandise exports from United Arab Emirates which shows the lowest dependency on hydrocarbon. Reasons for the same can be accounted to exportation activities developed in Dubai.

While hydrocarbon sectors makes up to almost 28\% at constant prices (Based on 2000 GDP), the manufacturing sector accounts to less than $9 \%$ of GDP on average for all GCC countries.

Non-hydrocarbon GDP, in \% of total GDP

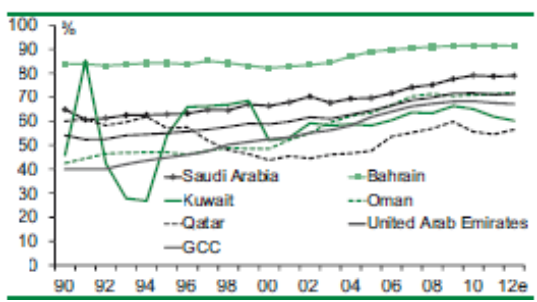

Figure 6. Non Hydrocarbon GDP, in \% of total GDP

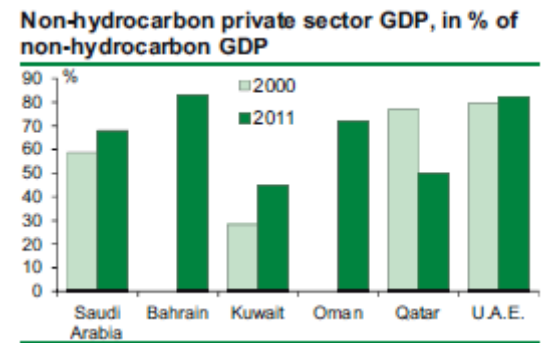

Figure 7. Private sector GDP - non hydrocarbon

According to sources like IIF, BNP Paribas, IMF and Central Banks, the following has been noted as depicted in Figure 6. Qatar's GDP dependency on hydro carbons is up to $44 \%$ and Saudi Arabia's is up to $21 \%$; while Bahrain, due to its low level of resources, generates more than $92 \%$ of revenues from non oil sectors. Contributions to non oil sectors is most remarkable in Oman with a rise of GDP from 43\% from 1990 to $71 \%$ in 2010. Generally, shares of non hydrocarbon GDP has raised in GCC countries from 54\% to $72 \%$ from 1990 to 2010. The only exception is Qatar; where the development of natural gas production in 1990 has led to a slower trend.

Levels of change in Non Oil GDP from private sectors give a better approximation of level of dependence on revenue generation from sectors. According to the Figure 7 released by Central Bank, IIF and BNP Paribas, Kuwait and Qatar are most dependent on oil based incomes on the public or private sector. Private sectors share of Non Oil GDP does not exceed 50\% for both Kuwait and Qatar. This figure has increased in Kuwait from 1990 compared to Qatar as Kuwait's economic diversification is highly dependent on the government. However, a remarkable change from this pattern can be noted in Bahrain and UAE (Dubai); which plays a major role on non oil GDP as these countries lack hydrocarbon resources and lays huge emphasis on encouraged investments in the private sector. Oman and Saudi Arabia are in an intermediate position as private sectors contribute to about $70 \%$ of non oil GDP. 
GCC Countries are more dependent on oil sectors regardless of the selections criteria sued liek budget, exports or GDP. Combining the 3 indicator would show that Kuwait is the most dependent with a more or less similar dependency in Saudi Arabia, Oman and Qatar. The only exceptions in this would be UAE and Bahrain, even though a large part of their business in indirectly linked to regional oil cycles.

\section{Results and Analysis}

GCC claims for about $30 \%$ of the World's oil reserves and $20 \%$ of Natural Gas reserves. GCC's World production shares in oil and natural gas accounts to $23 \%$ and $11 \%$ respectively. Essentiality of Diversification can be accounted to Uncertainty over future prospects for oil income and Need to create jobs.

According to Aussaoui estimates (Aissaoui, June 2013); GCC production could level off by 2025 before beginning to contract as of 2055, with a sharp decline by 2100 . In terms of disposable oil income per capita, the survey shows that the GCC countries are relatively stable on average, although Saudi Arabia reports a notable decline, from an historical average of $\$ 6,275$ to $\$ 4,785$, mainly due to the doubling of its population by 2050 .

According to 2012 World Outlook by the International Energy Agency (IEA). Prospects of a long terms decline could be less favourable for certain countries like Saudi Arabia. Firstly, there has been a strain in oil pricing trends due to US and Iraq oil production and the development of Natural Gas at the world level. Secondly, oil consumption in GCC countries increase by a $5 \%$ a year accounting to demographic momentum and industrial development. In Saudi Arabia, oil consumption has doubled since 2000. All this relates to the fact that in a medium and long term perspective, oil income is under pressure.

The need to create jobs for national populations have largely motivated economic diversification in Gulf Countries. In certain countries with a population of less than a million nationals (UAE, Bahrain and Qatar), unemployment is a relatively negligible problem. The official unemployment rate is less than $3 \%$ of the active population. Other countries - mainly Saudi Arabia and Oman - are confronted with unemployment problems that are virtually structural due to massive demographic pressure and an economic development model based on the development of hydrocarbon sector and industrial sectors that do not create many jobs. (Aissaoui, June 2013).

Rapid Economic development has created enormous labour needs which call for foreign labour. It is interestingly noted that Foreign Labour are generally employed in Private sectors while National populations mainly hold public sector jobs in a kind of income redistribution systems. Private sector jobs do not contain incentives or they lack the skills to hold a private sector job. In general while $90 \%$ of nationals hold public sector jobs, $90 \%$ of private jobs are held by expatriates as demonstrated in Figures 8 and 9 generated by the Central Banks. NCB and BNP Paribas.

Breakeven oil prices

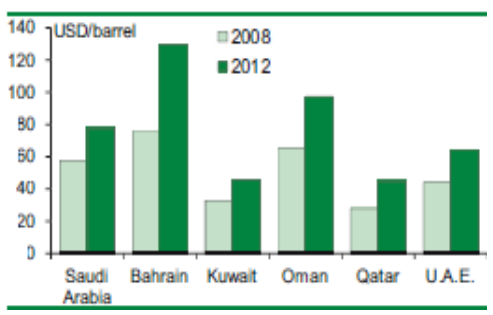

Figure 8. Private sector employment by nationality
Private sector employment by nationality
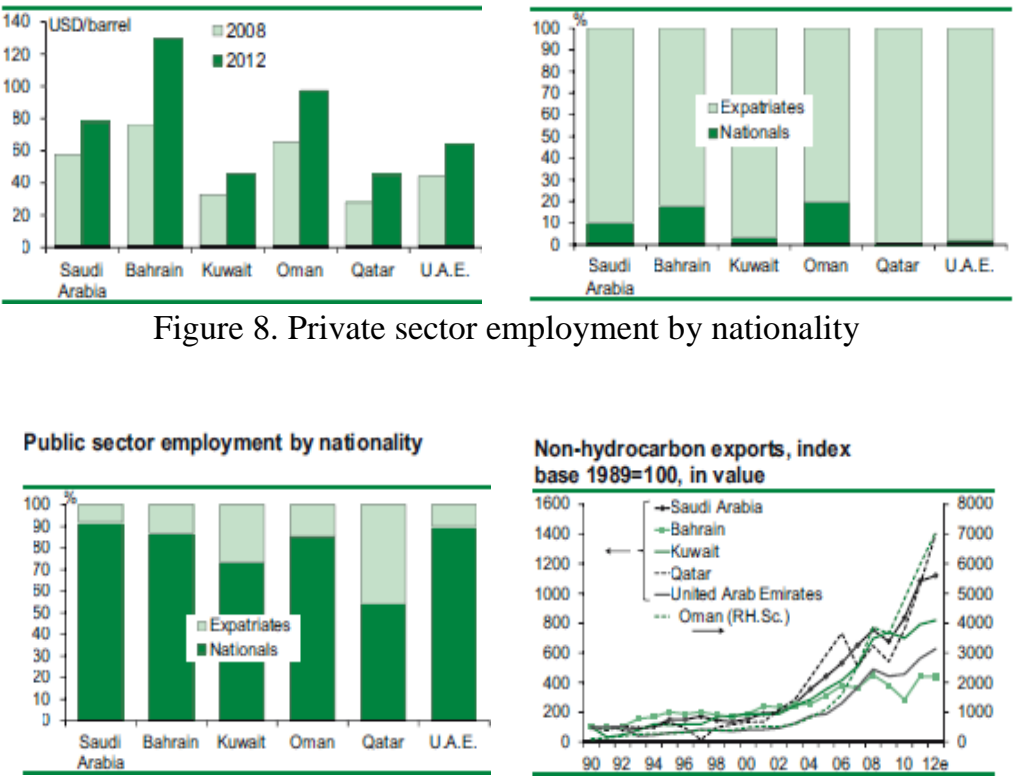

Figure 9. Public sector employment by nationality 
Mixed results have been generated as a result of diversification policies, which has developed a few non oil sectors, but has not created sufficient impact on the job market. Lion's share of budget and export revenues still lie on Oil and Natural Gas sectors.

Public finances have denoted very little change in the share of budgets and export revenues since 1990. The change in oil prices per barrel necessary to balance the budget have shown that in some cases the dependency on public finances have increased. This is further depicted in Figure 10 by IIF.

The budget breakeven price 3 rose sharply in recent years, from $\$ 50$ per barrel in 2008 to about $\$ 70$ per barrel in 2012. The situation varies widely between countries. Kuwait, Qatar and UAE are in an acceptable position while the vulnerability of Saudi Arabia and especially Oman is much stronger, with an equilibrium price that is approaching current market prices, at $\$ 78$ and $\$ 97$ in 2012, respectively. With a breakeven price of $\$ 130$ in 2012 , the situation in Bahrain is the least sustainable and should continue to deteriorate, at least in the short term.(Devaux, July - August 2013).

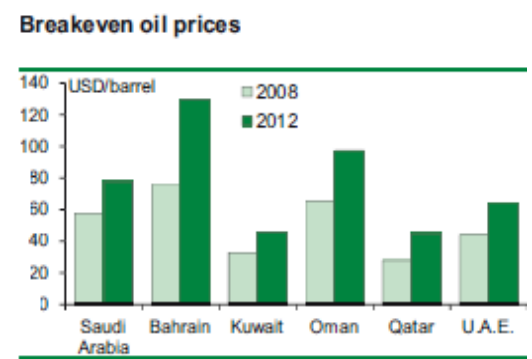

Figure 10. Break even oil prices

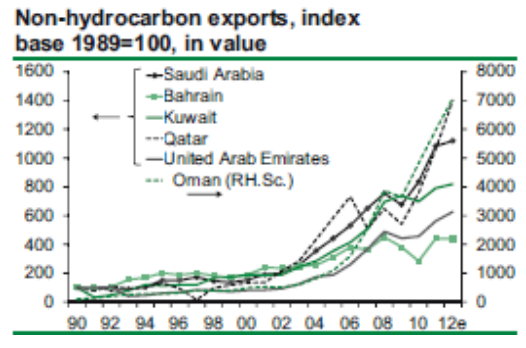

Figure 11. Non hydrocarbon exports

Export revenues show a high dependency on oil sectors in the first look, but a detailed look at the export trends in non oil sectors denote a positive increase from the onset of 2000 in all GCC countries. This has been denoted in Figure 11 by IIF and BNP Paribas.

Oman, Qatar and Saudi Arabia show a growth that is strongest when compared to Kuwait. Moreover, UAE and Bahrain have the most diversified economies, which has non oil exports growing at a slow, but steady pace. Tourism, Finance and transport Services contribute to this export revenue.

Various Factors like rapid growth of Non Oil GDP since 2000, Momentum in service sector and Other relatively mild gearing effects show that diversification is on a slow steady rise.

Rapid growth of GDP since 2000 shows interesting findings. Bahrain has the least dependent GDP. Strongest diversification of Oil producing countries was denoted in Saudi Arabia with 80\% of its GDP in 2012 coming from Non Oil Sectors. Qatar has the least diversified economy and has shown a negative trend when compared to $56 \%$ in 2012 and 60\% in 1990. (Devaux, July - August 2013, p. 22) The growth of non oil GDP however, shows a very strong increase while Saudi Arabia reported weaker growth as depicted in Figure 12 by IIF and BNP Paribhas.

Services has been the most dynamic sector so far with an average growth of $2.8 \%$ between 1991 and 2009 . Extraction sectors denoted to less than $1 \%$ and manufacturing industries showed less than $0.5 \%$ growth of service sector is noticeable in Qatar and Bahrain with an $+6.2 \%$ and $+5.3 \%$ on an average. 


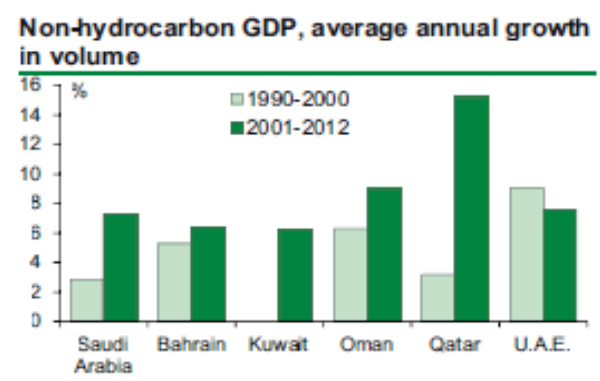

Figure 12. Non hydrocarbon GDP

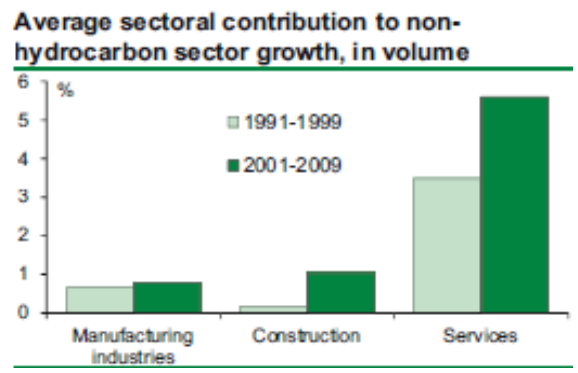

Figure 13. Average sectorial contribution to non hydro carbon growth

\section{Conclusion}

The GCC economies approach in continuing to maintain a more pro business environment, sound financial systems which help it to weather financial crises well and rise of potential work force provides it with a golden opportunity to push through reforms and further encourage the growth of non hydrocarbon sectors.

These changes will have national, regional and international business implications. GCC economies will leverage in being a hub between the West and the East. Banking on their sound financial system, they could become and international centre for Islamic Finance. The Gulf could, in addition; be a staging post for South to South investment (Note 1). Expanding these roles will also leverage job opportunities for millions of young university graduates between now and 2025.

\section{References}

Aissaoui. (2013). Saudi Arabia's Economic Diversification: Progress in the context of the GCC and challenges. Saudi Arabia: Apicorp Research. Economic Commentary, 8(6).

Arcadis. (2013). Middle East Construction Boom Risks to Peak Between 2014-19. London: s.n.

Austrlian Government. (2005). More than Oil: Economic developments in Bahrain, Kuwait, Oman, Qatar and UAE, Canberra: Common Wealth of Australia. Department of Foreign Affairs and Trade, Austrlian Government.

Booz, \& Company. (2012). The Rationale for PPPS in the GCC. Partnerships for Transformation using public private partnerships in the GCC (p. 3).

Devaux, P. (2013). Economic Diversification in GCC. BNP Paribas Conjoncture, 17.

Gupta, R. (2013). Qatar ranks 40th globally in World Bank Ease of Doing Business' report, Doha. Qatar, BQ Doha.

Human Development Network. (1998). Education in Middle East and North Africa. Morocco: s.n.

IMF. (2013). Saudi Arabia: 2013 Article IV Consulation.

Luciani, G. (2012). GCC Industrial Exports and the Controversy. Geneva: Gulf Research Center Foundation.

PwC Middle East Projections. (2013).

PwC. (2013a). Beyond Oil: Outlook for Gulf Economies. Global Economy Watch, 3.

PwC. (2013b). Interview with PwC Middle East. Global Economic Watch, 2. 
Samya, B. S. T. R. D. O. R. (2011). Gulf Cooperation Council Countries. s.1.: IMF.

The World Bank. (2008). The Road not travelled: Education reform in the Middle East and Africa. Washington DC: The International Bank for Reconstruction and development.

World Bank and PwC. (2014). Key Themes and Findings. Paying Taxes, 2014, 4.

World Bank. (2013). Doing Business 2014: Understanding regulations for small and medium sized enterprises. Washington DC: World Bank Group.

World Travel \& Tourism Council. (2014). Economic Impact: Saudi Arabia. Travel and Toursim.

Zughaibi, K., \& Kabbani, B. (2014). GCC Economic Overview. Retrieved from http://www.gulfbase.com/GCC/AboutGCC?pageID=93

\section{Note}

Note 1. Investment flows between E7 and other emerging economies.

\section{Copyrights}

Copyright for this article is retained by the author(s), with first publication rights granted to the journal.

This is an open-access article distributed under the terms and conditions of the Creative Commons Attribution license (http://creativecommons.org/licenses/by/3.0/). 